\title{
ЄВРОПЕЙСЬКИЙ ДОСВІД ПРОФЕСІЙНОЇ ПІДГОТОВКИ МАЙБУТНЬОГО ВЧИТЕЛЯ МУЗИЧНОГО МИСТЕЦТВА
}

\section{Прокопчук B. I.}

\section{ВСТУП}

Освіта як основа духовно-культурного, соціально-економічного розвитку суспільства $\epsilon$ державним пріоритетом будь-якої країни. Очевидно, що модернізація освіти $\epsilon$ важливим фундаментом соціальнокультурного прогресу соціуму. Сучасний стан реформування системи освіти в Україні як середньої, так і вищої ланок зумовлений вимогами часу, інтеграцією у світовий, зокрема європейський, освітній і науковий простір, забезпеченням іiі конкурентоспроможності в міжнародній спільноті, що висуває нові вимоги до якості підготовки майбутніх учителів, зокрема й музичного мистецтва, та загострює необхідність вивчення зарубіжного досвіду в цьому напрямі.

Одним із пріоритетів розвитку вищої освіти у світі $\epsilon$ інтернаціоналізація як приєднання національних освітніх інституцій до глобального освітнього простору, що актуалізує потребу у вихованні молодого покоління, здатного до міжкультурної взаємодії у світовому багатонаціональному полікультурному суспільстві. Отже, зазначені процеси підвищують значимість мистецької освіти й підготовки вчителя музичного мистецтва, зокрема, як носія й провідника культурно-мистецьких цінностей.

Дослідження в галузі музичної педагогіки, розвиток музичної освіти усіляко підтримує Всесвітня організація освітян у галузі мистецтва Міжнародне товариство музичної освіти (International Society for Music Education - ISME), що засноване Міжнародною музичною радою ЮНЕСКО в Брюсселі 1953 р. на конференції «Для стимулювання музичної освіти як невід'ємної частини загальної освіти». Воно охоплює учасників із понад 80 країн світу: від педагогів з раннього музичного виховання до викладачів педагогічних університетів i консерваторій. Товариство сприяє обміну досвідом i глобальній міжкультурній співпраці для взаєморозуміння серед музичних педагогів усього світу, а також декларує пряму залежність ефективної музичної освіти від якісної підготовки кваліфікованих педагогів ${ }^{1}$.

${ }^{1}$ ISME: International Society for Music Education. URL: https://www.isme.org/about (дата звернення: 27.04.2020). 
У Педагогічній Конституції Європи наголошується, що майбутнє всіх країн, народів, їх співдружність великою мірою залежать від якісної підготовки майбутніх педагогів, а об'єднавчий європейський процес потребує виховання сучасної людини, здатної до мирного й злагодженого співжиття в полікультурному суспільстві ${ }^{2}$. Тому вивчення європейського досвіду підготовки педагогічних кадрів у галузі музичного мистецтва $\epsilon$ важливим для впровадження кращих досягнень у вітчизняних вищих навчальних закладах і в контексті виховання конкурентоспроможного молодого покоління, здатного до культуротворчих утілень у мінливих світових перетвореннях.

Різні аспекти музично-педагогічної освіти висвітлені в порівняльнопедагогічних дослідженнях Н. Абашкіної, Т. Десятова, Н. Лавриченко, Л. Леферда, О. Локшиної, О. Матвієнко, Н. Ничкало, Б. Наврочинського, Р. Пахочинського, Л. Пуховської, А. Сбруєвої, Я. Фронтчака та ін.

Професійна підготовка педагогічних кадрів різних європейських країн, зокрема, у галузі музичного мистецтва постала предметом вивчення багатьох вітчизняних і зарубіжних дослідників, таких як Є. Вишневська, С. Гаєвський, Р. Гоздецька, І. Кривохижа, Г. Ніколаї, В. Павленко, А. Пастернак, Я. Проснак, М. Пшиходзінська (Польща), Й. Васютова, Р. Вілдова, Л. Подхалова, В. Спілкова (Чехія), Н. Базелюк, С. Гринюк, К. Котун, Л. Ляшенко, П. Смальберг (Фінляндія), Л. Волинець, Г. Коган, Н. Кошарна (Швеція), В. Семилетко (Норвегия), Й. Абель, Г. Белленберг, Д. Беннер, Ф. Бонзак, В. Брайнін, Р. Нойманн, І. Сташевська, Е. Терхарт, К. Червенко (Німеччина), Т. Харченко (Франція), К Біницька, T. Кошманова, Л. Пуховська, В. Яковлєв та ін. Проте нині актуалізується потреба в систематизації й узагальненні зарубіжного досвіду підготовки майбутніх учителів музичного мистецтва щодо використання найкращих досягнень в українській вищій школі.

\section{1. Професійна підготовка вчителів музичного мистецтва в країнах Східної Європи}

У Польщі, як і в більшості європейських країн, музику (музичне мистецтво) у загальноосвітній школі викладає вчитель-класовод, якого готують у вищих педагогічних навчальних закладах. Так, викладати мистецтво (музичне мистецтво, музику тощо, які включені в інтегрований предмет мистецтво) у школі мають право ті, хто закінчив педагогічний відділ університету (з попередньою музичною освітою), вищий педагогічний навчальний заклад і музичний вищий навчальний

\footnotetext{
${ }^{2}$ Педагогічна Конституція Європи. Преамбула. Вища освіта України. 2013. № 3. C. 111 . 
заклад (музичну академію) з додатковою педагогічною кваліфікацією, причому у вищих школах, університетах та академіях педагогічного напряму здобувається кваліфікація вчителя музики основної школи, а в музичних академіях, окрім цього, - учителя музики 3 додатковою спеціалізацією аніматора музичної культури, релятивного співу, елементарного музикування К. Орфа, ритміки Ж. Далькроза тощо ${ }^{3}$.

У результаті освітньої реформи з 2000 р. підготовка вчителів музики здійснюється за напрямом «Художня освіта у галузі музичного мистецтва» (у кінці XX ст. фахівців готували лише за напрямом «Музичне виховання»), крім того, у вищих педагогічних школах та університетах відкрито спеціальність «Мистецька освіта», «Початкове навчання», «Дошкільне виховання» ${ }^{4}$.

У професійній підготовці майбутнього вчителя музичного мистецтва велика увага приділяється не лише інструментальній підготовці, а й ритмічному вихованню. Зокрема, важливими $є$ вміння вільної імпровізації на фортепіано, створення пластичних інтерпретацій музичних творів, організація ритмічного виховання дітей, ритміка терапевтична для дітей з особливими потребами тощо.

Типовим у навчанні вчителя є поєднання двох спеціальностей, а саме: «Музика» та «Початкове навчання», «Польська мова» (іноземна), «Опікунська педагогіка», «Культурно-освітня педагогіка» тощо - 3 отриманням спеціалізації «інструментальна педагогіка», «музикотерапія», «інструктор-керівник ансамблів», «органіст (костьольна музика)», «рух з музикою-танок-музичний театр» ${ }^{5}$.

Звернімо увагу на фахові компетентності в підготовці вчителів музики, а саме: володіння фаховими методиками; психологопедагогічні знання для реалізації естетично-виховної функції мистецтва й усебічного розвитку учнів; реалізація індивідуального підходу для задоволення індивідуальних навчально-творчих потреб учнів; уміння застосовувати, передавати, поглиблювати, інтегрувати набуті знання зі знаннями 3 інших галузей; здатність розробляти, застосовувати, удосконалювати та адаптувати системи керування освітнім і художньоестетичним процесом; володіння й застосування інформаційних технологій в освітньому процесі; поглиблене знання іноземних мов тощо.

${ }^{3}$ Ніколаї Г. Європейські моделі підготовки вчителів музики. Педагогічні науки : збірник наукових праць. Суми : Сум. ДПУ ім. А.С. Макаренка, 2008. Ч. III. C. $142-150$. C. $147-149$.

Ніколаї Г.Ю. Розвиток музично-педагогічної освіти в Польщі (XX століття) : автореф. дис. ... докт. пед. наук : 13.00.01. Київ, 2008. 43 с. С. 22.

${ }^{5}$ Там само. С. 22-23. 
Відповідно, програмні результати навчання майбутніх учителів музичного мистецтва включають володіння методикою педагогічної діяльності й практичним досвідом іiі застосування; знання освітнього процесу для адаптації навчальної програми до потреб і можливостей учнів; знання теорії та проблем сучасної мистецької дидактики; практичну й психологічну готовність до виконання професійних завдань; психолого-педагогічні знання для розуміння процесів виховання, викладання, розвитку, адаптації, соціалізації; здатність удосконалення власної педагогічної майстерності; уміння комунікації 3 усіма учасниками педагогічної діяльності й навчального процесу та ораторську майстерність; здатність естетичної чутливості, емпатії ${ }^{6}$.

Наприклад, Жешувський університет (Uniwersytet Rzeszowski), що створений 2001 р. з'єднанням трьох самостійних вищих навчальних закладів (Жешувської Вищої педагогічної школи, філії Університету Марії Кюрі-Склодовської в м. Жешуві, Жешувського заміського економічного факультету Краківської сільськогосподарської академії ім. Г. Коллонтая) сьогодні $є$ найбільшим вищим навчальним закладом південно-східної Польщі та реалізовує навчання за 55 напрямами. Навчання здійснюється на 12 факультетах, серед яких - педагогічний факультет (за напрямом «Педагогіка»), факультет мистецтва (за напрямами «Графіка», «Візуальні мистецтва») та музичний факультет, який створений на базі Інституту музики (за напрямами «Художня освіта в галузі музичного мистецтва», «Інструменталістика» та «Джаз і розважальна музика») $)^{7}$.

Навчання в Інституті музичного мистецтва (Instytut Muzyki) Зеленогурського університету (Uniwersytet Zielonogórski) здійснюється за чотирма напрямами класичної й популярної музики: методичний (викладання музики), виконавський (гра на інструментах, спів, диригування), творчий (композиція, аранжування) та популяризація мистецтва (анімація музичної культури). Випускники спеціальності «Художня освіта в галузі музичного мистецтва» («Edukacja artystyczna w zakresie sztuki muzycznej») отримують кваліфікацію вчителя (викладача), лектора, інструменталіста (органіста), вокаліста, аніматора й організатора у сфері культури та мистецтва, диригента, композитора, звукорежисера тощо й право викладати музичне мистецтво в

${ }^{6}$ Rozporządzenie Ministra Nauki i Szkolnictwa Wyższego z dnia 25 lipca 2019 r. w sprawie standardu kształcenia przygotowującego do wykonywania zawodu nauczyciela (Dz.U. 2019 poz. 1450) : Dziennik Ustaw Rzeczpospolitej Polskiey. URL: http://prawo.sejm.gov.pl/isap.nsf/DocDetails.xsp?id=WDU20190001450 (дата звернення: 28.04.2020).

7 Uniwersytet Rzeszowski. URL: https://www.ur.edu.pl/ua/wydzialy/wmuz (дата звернення: 29.04.2020).

606 
початковій школі, дошкільних і позашкільних навчальних закладах, професійних та аматорських вокальних і вокально-інструментальних ансамблях, у сфері анімації та популяризації музичного мистецтва тощо ${ }^{8}$.

Як зазначалося, саме спеціальність «Художня освіта в галузі музичного мистецтва» серед інших дає змогу викладати мистецтво в основній школі. Така можливість також надається здобувачам освіти й інших спеціальностей i напрямів (наприклад, «Виконавство», «Інструменталістика», «Джаз» тощо), які в рамках педагогічних студій мають додатково пройти педагогічну підготовку (отримати педагогічний фах), опанувавши блок психолого-педагогічних (педагогіка, музична педагогіка, психологія, психологія мистецтва), навчально-дидактичних (музична дидактика, методика викладання фахових дисциплін - за спеціальністю), додаткових (композиція з елементами звукового втілення, джазова музика, музична дидактика з елементами арт-терапії, вокал - на вибір) наук, практику (педагогічну й навчальну (методичну) $)^{9}$.

У Чеській Республіиі до ХХІ ст. не було вимог до професії вчителя щодо отримання обов'язкової вищої освіти. Ситуація змінилася докорінним чином наприкінці ХХ ст. внаслідок реформ в освітній галузі, що охопили середню та вищу ланки, зокрема стосовно змісту і якості підготовки педагогічних кадрів. Болонський процес на початку XXI ст. став рушійним дороговказом освітніх оновлень у вищій школі щодо створення загальноєвропейського освітнього простору й упровадження двоступеневої системи вищої освіти для педагогічних закладів вищої освіти.

Національна програма розвитку освіти в Чеській Республіці. Біла книга (2001 р.) ${ }^{10}$ стала головним документом, що визначив нові вимоги до професійної підготовки майбутніх учителів, на основі якого прийнято Закон «Про педагогічних працівників» від 24.09.2004 № 563/2004 щодо означення положень i вимог щодо набуття професійної кваліфікації, рівнів професійної підготовки, вимог щодо виконання педагогічної діяльності й професійних обов'язків тощо для вчителів і педагогічних працівників різних галузей та освітніх ланок ${ }^{11}$.

\footnotetext{
${ }^{8}$ Uniwersytet Zielonogórski: Instytut Muzyki UZ. URL: http://www.imu.uz.zgora.pl/ (дата звернення: 29.04.2020).

${ }^{9}$ Ibid.

${ }^{10}$ Národní program rozvoje vzdělávání v České republice. Bílá kniha [National Programme for the Development of Education in the Czech Republic White Paper]. Prague: Ministry of Education, Youth and Sport, 2001. 105 p. URL: http://www.msmt.cz/uploads/ VKav_200/Bila_Kniha_2001/whitepaper.pdf (дата звернення: 29.04.2020).

${ }_{11}$ Zakon o pedagogickych pracovnicich № 563/2004. URL: https://www.zakonyprolidi.cz/ cs/2004-563 (дата звернення: 29.04.2020).
} 
Так, у Законі «Про педагогічних працівників» зазначено, що вчитель початкової та середньої освіти повинен здобути ступінь магістра в закладі вищої освіти за акредитованою освітньопрофесійною програмою в галузі знань, що відповідає «природі й характеру» викладання предмета. Зокрема, учитель предметів художньої (мистецької) спеціалізації здобуває кваліфікацію за програмою в галузі мистецтва художньо-педагогічного спрямування, яка відповідає методології викладання мистецьких (художніх) предметів ${ }^{12}$.

Зміст освітньої програми професійної підготовки вчителя початкової ланки складається 3 п'яти компонентів: загальноосвітнього, предметного (академічного й дидактичного), психолого-педагогічного та спеціалізації (професійна кваліфікація). Загальноосвітній компонент наскрізно проходить через I і II рік навчання (переважно знання й навички в галузях гуманітарних $\mathrm{i}$ соціальних наук), що має культурологічне спрямування. Предметний компонент (1-3 курси) зосереджений на предметах, що вивчаються учнями в початковій загальноосвітній школі (чеська мова й література, математика, музика, мистецтво, іноземна мова, батьківство тощо). Психолого-педагогічний компонент, що переважно вивчається упродовж усього періоду навчання, містить блок теоретичних і практичних дисциплін у галузі педагогіки й психології (історія, теорія та філософія освіти, загальна дидактика, первинна педагогіка, методологія педагогічних досліджень, порівняльна й альтернативна педагогіка, психологія розвитку, освітня та соціальна психологія тощо). Компонент дидактики, що опановується впродовж останніх років навчання, охоплює дисципліни, які сприяють розвитку вмінь і навичок, спрямованих на адаптацію навчального матеріалу 3 урахуванням індивідуальних і вікових особливостей учнів. Компонент спеціалізації вивчається протягом останніх трьох років навчання та є повним блоком дисциплін і курсів (глибоке опанування та практика) у рамках обраної спеціалізації, а саме таких спеціалізацій, як музика, мистецтво, театральне мистецтво, іноземна мова, спеціальна педагогіка тощо ${ }^{13}$.

${ }^{12}$ Zakon o pedagogickych pracovnicich № 563/2004. URL: https://www.zakonyprolidi.cz/ cs/2004-563 (дата звернення: 29.04.2020).

13 Vašutová J., Spilková V. Teacher Education in Czech Republic. European Dimensions of Teacher Education: Similarities and Differences / Edited by Milena Valenčič Zuljan and Janez Vogrinc. Ljubljana: Faculty of Education ; Kranj : The National School of Leadership and Education, 2011. S. 193-224. S. 201-202. 


\section{2. Професійна підготовка вчителів музичного мистецтва в країнах Північної Європи}

Актуальність дослідження досвіду професійної підготовки вчителя музичного мистецтва в країнах Північної Свропи (Скандинавських країнах) зумовлена лідируючими позиціями за якістю шкільної освіти та престижем педагогічної професії в цих країнах.

У Фінляндї якісна професійна підготовка учителів у закладах вищої освіти, що повинні отримати ступінь магістра для роботи в загальноосвітній школі, є одним із головних освітніх і державних завдань. Загалом освітня політика країни є частиною теорії побудови «суспільства добробуту» (welfare society), де учні та здобувачі вищої освіти виявляють усвідомлене розуміння того, що саме вони $\epsilon$ будівельниками свого навчання, компетенцій і сприйняття світу ${ }^{14}$.

Зауважимо, оскільки професія вчителя (педагога) $€$ однією 3 найпрестижніших у Фінляндії, існує досить серйозна конкуренція серед абітурієнтів і випускників вищих педагогічних навчальних закладів. Так, із 30\% кращих випускників педагогічних факультетів лише близько $10 \%$ після ретельного відбору будуть працювати в школах ${ }^{15}$.

Виховання молодого покоління в середній i вищій школі спрямоване на збереження та розвиток фінської національної культури й мистецтва, створення сприятливого психологічного клімату в освітньому середовищі, виховання поваги до прав i свобод, справедливості й толерантності. Навчання грунтується на принципах гнучкої стандартизації, відсутності розподілу предметів на пріоритетні й другорядні («несерйозні»), педагогічного балансу між консерватизмом i прогресивністю, досвідченістю та інноваційним мисленням, фахової відповідальності й узгодженості, компліментарності та свободи.

У школі й вищому навчальному закладі мистецькі дисципліни об'єднані в предметні блоки. Вагому роль у розвитку молоді відіграє предмет «Музика» та інші предмети художньо-естетичного циклу як такі, що розвивають обидві півкулі мозку. Тобто зрозуміло, що предмети «Музика», «Образотворче мистецтво» тощо є обов'язковими в навчальній програмі основної школи. У навчанні велику увагу приділяють вивченню національної музичної культури, також вагомого

${ }^{14}$ Скиба М. Освіта для турбулентного світу. Український Інститут майбутнього. Київ, 2017. 80 с. С. 25-36. URL: https://uifuture.org/uk/post/osvita-dla-turbulentnogosvitu-dopovid-pdf_332 (дата звернення: 29.04.2020).

${ }^{15}$ Котун К. Особливості професійної підготовки майбутніх вчителів початкової школи у Фінляндії. ДВНЗ «Переяслав-Хмельницький державний педагогічний університет ім. Г. Сковороди». Київ : Гнозис, 2012. Том I (1) : Тематичний випуск «Міжнародні Челпанівські психолого-педагогічні читання». С. 309-315. С. 309. 
значення набувають знання практичного характеру. Передусім перевага надається грі на музичних інструментах: маючи широкий вибір наданих музичних інструментів (від сопілки до бас-гітари), учні можуть опанувати будь-який на вибір упродовж усього періоду навчання в школі.

Також результатом реформи 2014 р. в освітньої галузі, яка вважається взірцевою, $є$ перенесення акцентів зі стандартних уроків на міждисциплінарність; пріоритетність проектних завдань у навчанні, що спрямовані на співпрацю й командну взаємодію учасників; об'єднання предметів у предметні блоки; наявність електронних щоденників; до сьомого класу лише усне оцінювання; відсутність практики викликання учня «до дошки»; можливість писати в зошитах олівцем і коригувати написане багато разів; заміна атестації на щорічний «план професійного розвитку» вчителя; свобода та самостійність для педагогів у розробленні навчальної програми тощо ${ }^{16}$.

У Швеціï, де педагогічна освіта стала окремим напрямом вищої освіти в 1977 р., важливими іiі напрямами виокремлюються такі: практико-орієнтована підготовка майбутніх учителів, орієнтування на освіту протягом життя, компетентнісна підготовка, полікультурність освіти, спрямованість на розвиток наукових досліджень і широке використання інформаційних технологій у професійній діяльності, дистанційна освіта вчителів тощо ${ }^{17}$.

Педагогічна практика, об'єднуючи теоретичну й практичну підготовку студентів, $€$ важливим невід'ємним компонентом удосконалення професійних компетентностей майбутніх учителів музичного мистецтва. Ї̈̈ зміст спрямовано на самостійне проведення уроків, вивчення особистості дитини та дитячого колективу різних вікових категорій, тісну співпрацю 3 учнями й батьками (функції класного наставника), організацію позакласної та соціальної роботи, участь у системі шкільного самоврядування, планування й самоаналіз власної педагогічної діяльності тощо ${ }^{18}$.

Загальна мистецька освіта $є$ важливим засобом гуманізації та соціалізації суспільства, творчого самовираження й розвитку

${ }^{16}$ Скиба М. Освіта для турбулентного світу. Український Інститут майбутнього. Київ, 2017. 80 с. С. 25-36. URL: https://uifuture.org/uk/post/osvita-dla-turbulentnogosvitu-dopovid-pdf_332 (дата звернення: 29.04.2020).

17 Коган Г. Професійна підготовка вчителів як складова педагогічної освіти Швеції. Науковий вісник Миколаӥвського державного університету ім. В.О. Сухомлинського. Серія «Педагогічні науки». 2010. Вип. 1.31. С. 112-119.

18 Попович Н., Буркало С. Досвід реалізації компетентнісного підходу у неперервній професійній підготовці вчителя музики прогресивних європейських країн. Музичне мистецтво в освітологічному дискурсі: науковий журнал. Київ, 2016. № 1. C. 14-19. C. 18. 
особистості. Важливим у підготовці вчителя музичного мистецтва $€$ формування естетичної, музичної, креативної та комунікативної компетентностей. Здобувачі мистецьких спеціальностей педагогічного спрямування опановують такі дисципліни, як музичні стилі, історія музики, слухання музики, композиція, виконавство (інструментальне, вокальне, танцювальне), сучасна музика тощо. Крім того, підготовка майбутнього вчителя музичного мистецтва спрямована на реалізацію програми «Мистецтво поза школою», яка $\epsilon$ складником програми загальноосвітньої школи, де учні заохочуються до участі в позашкільних мистецьких проектах, організованих учителями. У початковій школі навчання здійснює учитель-класовод, проте музику та інші предмети художньо-мистецького циклу (танець, візуальні мистецтва, літературно-драматичне мистецтво, ремесла тощо) викладає лише фахівець за профілем ${ }^{19}$.

Зазначимо, що випускники музичних навчальних закладів також можуть працювати в загальноосвітній школі, проте для цього обов'язково повинні додатково отримати педагогічну освіту, опанувавши дисципліни художньо-естетичного та психологопедагогічного циклу, про що свідчить аналіз сайту Стокгольмської королівської вищої музичної школи. Також існує широка практика підготовки вчителя основної школи не лише як педагога-музиканта (виконавця), a i як учителя-двопредметника iз зосередженням на викладанні дисциплін мистецького циклу ${ }^{20}$.

У Норвегії предмет «Мистецтво» є обов'язковим у загальноосвітній школі. Упродовж усього періоду навчання учні на вибір опановують один із художніх (мистецьких) напрямів, а саме: «Музика, танець $\mathrm{i}$ драма» або «Мистецтва, ремесла та дизайн». Зауважимо, що змістове наповнення кожного із цих напрямів складається 3 трьох компонентів: загальних предметів (базових), що $є$ спільними для обох напрямів, профільних і предметів за вибором. Зрозуміло, що професійна підготовка майбутніх учителів художньо-мистецьких спеціальностей у закладах вищої освіти також здійснюється за цими напрямами ${ }^{21}$.

19 Яковлев В. Досвід підготовки вчителя музики у зарубіжній професійній педагогічній освіті. Педагогічні науки. 2011. Вип. 1. С. 86-93. С. 87.

${ }^{20}$ Kungliga Musikhögskolan i Stockholm. URL: https://www.kmh.se/ (дата звернення: 29.04.2020).

21 Яковлев В. Досвід підготовки вчителя музики у зарубіжній професійній педагогічній освіті. Педагогічні науки. 2011. Вип. 1. С. 86-93. С. 88; Прокопчук В.И. Особенности профессиональной подготовки учителей музыкального искусства в Скандинавских странах. Proceedings of the 3rd International Scientific and Practical Conference "Challenges in Science of Nowadays» (April 6-8, 2020). Washington, USA : EnDeavours Publisher, 2020. P. 115-118. 


\section{3. Професійна підготовка вчителів музичного мистецтва в країнах Західної Європи}

У Німеччині традиційно двоступенева (бакалавр, магістр) підготовка вчителів музики здійснюється у вищих педагогічних i музичних школах, університетах, вищих школах мистецтв. Особливістю навчання $€$ його орієнтація не лише на обрану спеціалізацію, а й на навчальний заклад і регіон, де працюватиме майбутній педагог, що позначається на змісті програми. Навчання, де велику роль відіграє поєднання теорії і практики, складається з двох етапів: теоретичної підготовки у виші та практичної підготовки в школі (стажерська практика). Перший етап навчання завершується теоретичним державним іспитом і дає право студенту приступити до практичного етапу. Стажерська практика проходить у школі й охоплює відвідування уроків, самостійне проведення занять і під керівництвом ментора (учителя-методиста), вивчення спеціальних предметів тощо. Саме другий державний іспит (практичне застосування знань) засвідчує здатність і готовність студента до здійснення освітнього процесу як шкільного вчителя ${ }^{22}$.

Майбутні вчителі музичного мистецтва опановують теорію музики й музичну педагогіку, аналіз музичних форм і музикознавство, спів (вокал), хор і джазовий хор, класичний камерний ансамбль, читання партитур, розвиток слуху тощо. Окрім індивідуальних, групових, лекційних i семінарських занять, студенти залучаються до дослідницьких проектів, наукових і міждисциплінарних семінарів, «круглих столів» тощо. Частою $є$ практика поєднання здобуття спеціальності вчителя музики та іншої спеціальності. Випускник музичного закладу може викладати в базовій школі лише факультативи мистецького напряму, які є в Німеччині обов'язковими ${ }^{23}$.

Зміст музично-педагогічної освіти складається 3 педагогічного, музично-теоретичного та мистецько-практичного блоків. Так, Університет музики й театру ім. Фелікса Мендельсона Бартольді в Лейпцизі здійснює підготовку за музичним, співацьким і педагогічним напрямами, які охоплюють мистецько-практичні, музично-теоретичні та музично-педагогічні спеціалізації: рання музика, фортепіано (диригент), струнні інструменти (арфа), духові ударні інструменти, драматургія, драматичний інститут «Ганс Отто», класичний спів

22 Бобраков С. Становлення та розвиток системи професійної підготовки вчителів у Німеччині. Вісник Житомирського державного університету. Серія «Педагогічні науки». 2012. Вип. 65. С. 123-126.

23 Матвєєва О. Теоретико-методичні засади педагогічної діагностики якості вищої музично-педагогічної освіти : монографія. Харків : Щедра садиба плюс, 2014. 438 c. C. 185. 
(музичний театр), музикознавство, музична композиція, популярна музика (джаз), інститут церковної освіти й музична освіта. Інститут музичної освіти Університету складається 3 трьох факультетів (напрямів): інструментальна та вокальна педагогіка (сфера діяльності випускників: музична школа, керівник ансамблів, заклади дозвілля тощо); елементарна музична й танцювальна педагогіка (сфери діяльності: музичні, художні школи та загальноосвітні школи, заклади дозвілля й молодіжні центри, мистецькі й культурні товариства, театри танцю для дорослих і дітей, дитячі будинки, будинки престарілих, музичні центри освіти для дорослих, реабілітаційні центри, музичне виховання в церквах тощо) та викладання музики (шкільна музика) ${ }^{24}$.

Для музично-педагогічної освіти Aвстрії характерним в опануванні музичного мистецтва $є$ зосередження на його інтеграції 3 рухом, танцем, словом, театром, кіно тощо. В освітні програми включено багато навчальних дисциплін практичного спрямування (виконавського, танцювального, ритмопластичного тощо) $)^{25}$.

Так, Віденський університет музики та виконавського мистецтва (Universität für Musikunddarstellende Kunst Wien), який засновано в 1819 p., $€$ одним із найвідоміших університетів світу, що спеціалізується на виконавському мистецтві музики, театру й кіно та налічує 24 інститути (факультети), а саме: інститут підготовки композиторів, електроакустики та звукорежисури; управління музикою; музикознавства та інтерпретаційних досліджень; концертного (виконавського) фортепіано; струнних інструментів, гітари та арфи; ударних інструментів; камерної, ранньої та нової музики ім. Й. Гайдна; органної та церковної музики; співу та музичного театру; акторства та режисури; кіно й телебачення (Кіноакадемія Відня); музичної та рухової освіти (ритміка та музична фізіологія); музичної терапії; популярної музики; фортепіано і клавесина ім. Л. Бетховена в музичній освіті; струнних інструментів, гітари та арфи в музичній освіті; духових та ударних інструментів ім. Ф. Шуберта в музичній освіті; співу та голосових досліджень у музичній освіті ім. А. Сальєрі; хорового та ансамблевого диригування в музичній освіті; досліджень народної музики та етномузикології; музичної акустики; музичної соціології; менеджменту культури та гендерних досліджень; а також інститут

${ }^{24}$ Hochschule für Musik und Theater «Felix Mendelssohn Bartholdy» Leipzig. URL: https://www.hmt-leipzig.de/ (дата звернення: 29.04.2020).

${ }_{25}$ Мукашева А. Организация высшего музыкального образования в Чехии, Болгарии и Австрии: сравнительный аспект. Вестник Каз. НУ. Серия «Педагогические науки». 2014. № 1(41). С. 119-126; University of Music and Performing Arts Vienna. URL: https://www.mdw.ac.at/5/ (дата звернення: 29.04.2020). 
досліджень музичної освіти, музичної дидактики та початкової музики (елементарного музикування) ${ }^{26}$.

У Франизї професійна підготовка майбутнього вчителя мистецтва спрямована на підготовку студента як педагога-музиканта для викладання інструментального класу (факультативу) у школі й великою мірою як керівника-координатора для співпраці 3 культурномистецькими закладами (філармоніями, концертними залами, театрами, музеями художньо-мистецького профілю тощо), які на постійній основі слугують освітньо-мистецькими майданчиками для проведення шкільних уроків мистецтва ${ }^{27}$. Така співпраця освітньої та мистецької галузей через національні ресурсні центри дає можливість використовувати культурний простір культурно-мистецьких установ як освітній для оптимізації навчання учнів і слугує навчально-мистецькою практикою для студентів - майбутніх учителів мистецтва. Саме такий тісний зв'язок і творча співпраця школи, закладу вищої освіти й культурно-мистецьких установ через створення мистецьких майданчиків дають можливість організувати освітній простір як особливе навчально-розвивальне середовище для студентів та учнів.

Аналіз сайту Паризької вищої національної консерваторії музики й танцю, Ліонської національної консерваторії музики й танцю свідчить про тісну співпрацю між закладами та видатними діячами культури й мистецтва різних країн, яких залучають до освітнього процесу (майстер-класи, семінари, індивідуальна практика, мистецькі проекти), що $є$ важливим для реалізації освітніх завдань, інтегрування в зміст навчання регіональних i національних традицій, міжкультурної співпраці ${ }^{28}$.

У Великобританії концепція музично-педагогічної освіти спрямована на формування вчителя, що вміло поєднує функції керівника, методиста, організатора, наставника, консультанта, спостерігача, мотиватора, ініціатора, діагноста, експерта тощо. Навчальні дисципліни об’єднані в загальноосвітні, спеціальні та професійно-педагогічні блоки. Обов'язковим для роботи в школі $\epsilon$ статус кваліфікованого вчителя (QTS), що надається лише після складання спеціального іспиту. Крім того, система вищої педагогічної освіти характеризується демократичністю, тьюторською побудовою,

${ }^{26}$ University of Music and Performing Arts Vienna. URL: https://www.mdw.ac.at/5/ (дата звернення: 29.04.2020).

27 Conservatoire national supérieur de musique et de danse de Lyon. URL: http://www.cnsmd-lyon.fr/ (дата звернення: 28.04.2020); Conservatoire national supérieur de musique et de danse de Paris. URL: http://www.conservatoiredeparis.fr/ accueil/ (дата звернення: 29.04.2020).

${ }^{28}$ Ibid. 
відсутністю бюрократії та регламентації змісту дисциплін, практичною спрямованістю змісту навчання й належною увагою до педагогічної практики, скороченням лекційного часу (до $25 \%$ ) і зосередженістю на самостійній роботі студентів і самоосвіті (понад 60\%), персоналізацією навчання, добре розвинутим дистанційним навчанням, тісним співробітництвом між університетом і вчителями, протидією дискримінації, допомогою учням $\mathrm{i}$ студентам 3 емоційноповедінковими відхиленнями, повагою до релігійності й етнічного походження, пріоритетністю незалежності в понятті «професіоналізм учителя», акцентом на самовдосконалення та професійне зростання шляхом щорічних взаємних письмових відгуків та оцінок колег щодо оцінювання роботи кожного викладача тощо 29.

\section{ВИСНОВКИ}

У європейських інтегрувальних процесах у відповідь на виклики часу на шляху адаптації освітніх систем до потреб «суспільства знань» відбувається глибоке оновлення освіти й професійної підготовки педагогічних кадрів. В умовах глобалізації процес інтеграції європейських освітніх систем глибоко пов'язаний із національними педагогічними традиціями та особливостями історичного й соціальноекономічного розвитку країн. Зближення та модернізація національних систем підготовки вчителів здійснюється з урахуванням історикосуспільних відносин і традицій освіти країн і на основі визначених Європейською комісією у 2005 р. ключових компетенцій для професії та кваліфікації європейського вчителя, що поділяються на дві групи: компетенції, пов'язані з процесом навчання/викладання, і компетенції, орієнтовані на формування відносин здобувачів освіти. Також документ Європейської комісії визначає принципи, на яких будується процес підготовки вчителів: їх підготовку повинні здійснювати лише заклади вищої освіти; мобільність учителя; професія пов'язана 3 навчанням упродовж усього життя; в основі професії повинні лежати партнерські відносини, що забезпечать співпрацю ЗВО, школи та інституцій для проходження практики. Крім того, суттєві позитивні зміни в європейських країнах у ставленні до дітей з особливими освітніми можливостями визначають інклюзивну освіту важливою ланкою й детермінантою всієї модернізованої європейської освіти ${ }^{30}$.

${ }^{29}$ Соколова А.В. Професійна підготовка вчителя у системі педагогічної освіти Англії і Шотландії : автореф. дис. ... канд. пед. наук : 13.00.01. Одеса, 2009. 22 с.

30 Савина А.К. Развитие европейской системы образования в III тысячелетии: История развития системы образования в регионах мировой цивилизации. С. 32. URL: http://federalbook.ru/files/FSO/soderganie/Tom\%209/I/Savina.pdf (дата звернення 28.04.2020). 
Професійна підготовка вчителя музичного мистецтва в європейських країнах має свою специфіку, яка визначається сукупністю цінностей i соціально-культурними умовами, що й окреслюють зміст навчання. Разом із тим спільним $є$ двопредметна підготовка вчителя музичного мистецтва; опора на етичні норми професійної діяльності; наявність системи вимог до здобувачів професії (мотивація, відповідний загальний рівень розвитку, здатність до навчання, відповідність психологічним вимогам і системі цінностей, світогляду, поведінки тощо); індивідуалізація навчального процесу, що забезпечується багаторівневою професійною освітою 3 урахуванням попереднього рівня та профілю музичної підготовки студента; практична зорієнтованість освіти; поліпрограмність; гнучкість програм та організації навчального процесу; вагоме значення педагогічної практики (40-50\% навчального часу), підвищення ролі самостійної роботи студентів; упровадження інтегрованих предметних блоків шляхом об'єднання дисциплін; урахування регіонального аспекту в змісті навчання; тісна співпраця Міністерств освіти, культури 3 різноманітними інституціями, центрами, асоціаціями, об'єднаннями; міжнародне партнерство закладів освіти, шкіл, культурно-мистецьких інституцій; спрямованість змісту мистецької (музично-педагогічної) освіти на розуміння цінності культурного розмаїття світу, що $€$ необхідним для міжкультурної комунікації у світовому «діалозі культур » ${ }^{31}$.

\section{АНОТАЦІЯ}

Наукова розвідка присвячена європейському досвіду професійної підготовки майбутніх учителів музичного мистецтва у вищій школі. На основі порівняльно-педагогічного підходу здійснено аналіз, розкрито особливості фахової підготовки вчителя музичного мистецтва в європейських країнах (Польщі, Чехії, Фінляндії, Швеції, Норвегії, Німеччині, Австрії, Франції, Великобританії).

3'ясовано, що особливість професійної підготовки вчителя музичного мистецтва в європейських країнах визначається сукупністю цінностей, національними освітніми традиціями та соціальнокультурними умовами, що обумовлюють зміст навчання. Виокремлено спільні тенденції в професійній підготовці вчителя музичного мистецтва: двопредметна підготовка; наявність системи вимог до

31 Прокопчук В. Методологічна підготовка майбутнього вчителя музичного мистецтва в європейському освітньому просторі. Інноватика у вихованні : збірник наукових праць / упоряд. О.Б. Петренко ; ред. кол. : О.Б. Петренко, Р.Л. Сойчук, Т.С. Ціпан та ін. Рівне : РДГУ, 2020. Вип. 11. 
здобувачів освіти; індивідуалізація, гнучкість і поліпрограмність навчання; практична зорієнтованість освіти; підвищення ролі практики та самостійної роботи студентів; упровадження інтегрованих предметних блоків шляхом об'єднання дисциплін; урахування регіональних i національних культурних особливостей у змісті навчання; співпраця Міністерства освіти, Міністерства культури 3 різноманітними асоціаціями, об'єднаннями, центрами; міжнародна співпраця закладів освіти, шкіл, культурно-мистецьких установ; спрямованість змісту освіти на розуміння цінності культурного розмаїття світу, що є необхідним для міжкультурної комунікації у світовому «діалозі культур».

\section{ЛIТЕРАТУРА}

1. Бобраков С. Становлення та розвиток системи професійної підготовки вчителів у Німеччині. Вісник Житомирського державного університету. Серія «Педагогічні науки». 2012. Вип. 65. С. 123-126.

2. Коган Г. Професійна підготовка вчителів як складова педагогічної освіти Швеції. Науковий вісник Миколаївського державного університету ім. В.О. Сухомлинського. Серія «Педагогічні науки». 2010. Вип. 1.31. С. 112-119.

3. Котун К. Особливості професійної підготовки майбутніх вчителів початкової школи у Фінляндії. ДВНЗ «Переяслав-Хмельницький державний педагогічний університет ім. Г. Сковороди». Київ : Гнозис, 2012. Том I (1) : Тематичний випуск «Міжнародні Челпанівські психолого-педагогічні читання». С. 309-315.

4. Мукашева А. Организация высшего музыкального образования в Чехии, Болгарии и Австрии: сравнительный аспект. Вестник Каз. НУ. Серия «Педагогические науки». 2014. № 1 (41). С. 119-126.

5. Ніколаї Г. Європейські моделі підготовки вчителів музики. Педагогічні науки : збірник наукових праць. Суми : Сум. ДПУ ім. А.С. Макаренка, 2008. Ч. III. С. 142-150.

6. Ніколаї Г.Ю. Розвиток музично-педагогічної освіти в Польщі (XX століття) : автореф. дис. ... докт. пед. наук : 13.00.01. Київ, 2008. $43 \mathrm{c}$.

7. Образование каждому сейчас. Призыв к действию. EDUCATION EQUITY NOW: UNICEF. 20 c. URL: http://education-equity.org/wpcontent/uploads/2014/02/Call-for-Action-RUS-WEB_final.pdf (дата звернення: 29.04.2020).

8. Педагогічна Конституція Свропи. Преамбула. Вища освіта України. 2013. № 3. С. 111-116.

9. Попович Н., Буркало С. Досвід реалізації компетентнісного підходу у неперервній професійній підготовці вчителя музики 
прогресивних європейських країн. Музичне мистецтво в освітологічному дискурсі : науковий журнал. Київ, 2016. № 1. С. 14-19.

10. Прокопчук В. Методологічна підготовка майбутнього вчителя музичного мистецтва в європейському освітньому просторі. Інноватика у вихованні : збірник наукових праць / упоряд. О.Б. Петренко ; ред. кол. : О.Б. Петренко, Р.Л. Сойчук, Т.С. Ціпан та ін. Рівне : РДГУ, 2020. Вип. 11.

11. Прокопчук В.И. Особенности профессиональной подготовки учителей музыкального искусства в Скандинавских странах. Proceedings of the 3rd International Scientific and Practical Conference "Challenges in Science of Nowadays» (April 6-8, 2020). Washington, USA : EnDeavours Publisher, 2020. P. 115-118.

12. Савина А.К. Развитие европейской системы образования в III тысячелетии: История развития системы образования в регионах мировой цивилизации. С. 29-32. URL: http://federalbook.ru/files/ FSO/soderganie/Tom\%209/I/Savina.pdf (дата звернення: 28.04.2020).

13. Скиба М. Освіта для турбулентного світу. Український Інститут майбутнього. 2017. 80 c. URL: https://uifuture.org/uk/post/osvitadla-turbulentnogo-svitu-dopovid-pdf_332 (дата звернення: 29.04.2020).

14. Соколова А.В. Професійна підготовка вчителя у системі педагогічної освіти Англії і Шотландії : автореф. дис. ... канд. пед. наук : 13.00.01. Одеса, 2009. 22 с.

15. Яковлев В. Досвід підготовки вчителя музики у зарубіжній професійній педагогічній освіті. Педагогічні науки. 2011. Вип. 1. C. $86-93$.

16. Conservatoire national supérieur de musique et de danse de Lyon. URL: http://www.cnsmd-lyon.fr/ (дата звернення: 28.04.2020).

17. Conservatoire national supérieur de musique et de danse de Paris. URL: http://www.conservatoiredeparis.fr/accueil/ (дата звернення: 29.04.2020).

18. ISME: International Society for Music Education. URL: https://www.isme.org/about (дата звернення: 27.04.2020).

19. Kungliga Musikhögskolan i Stockholm. URL: https://www.kmh.se/ (дата звернення: 29.04.2020).

20. Národní program rozvoje vzdělávání v České republice. Bílá kniha [National Programme for the Development of Education in the Czech Republic White Paper]. Prague: Ministry of Education, Youth and Sport, 2001. 105 p. URL: http://www.msmt.cz/uploads/VKav_200/Bila_ Kniha_2001/whitepaper.pdf (дата звернення: 29.04.2020).

21. Rozporządzenie Ministra Nauki i Szkolnictwa Wyższego z dnia 25 lipca 2019 r. w sprawie standardu kształcenia przygotowującego do wykonywania zawodu nauczyciela (Dz.U. 2019 poz. 1450) : Dziennik 
Ustaw Rzeczpospolitej Polskiey. URL: http://prawo.sejm.gov.pl/isap.nsf/ DocDetails.xsp?id=WDU20190001450 (дата звернення: 28.04.2020).

22. Uniwersytet Rzeszowski. URL: https://www.ur.edu.pl/ua/wydzialy/ wmuz (дата звернення: 29.04.2020).

23. Uniwersytet Zielonogórski: Instytut Muzyki UZ. URL: http://www.imu.uz.zgora.pl/ (дата звернення: 29.04.2020).

24. University of Music and Performing Arts Vienna. URL: https://www.mdw.ac.at/5/ (дата звернення: 29.04.2020).

25. Vašutová J., Spilková V. Teacher Education in Czech Republic. European Dimensions of Teacher Education: Similarities and Differences / Edited by Milena Valenčič Zuljan and Janez Vogrinc. Ljubljana : Faculty of Education ; Kranj : The National School of Leadership and Education, 2011. P. 193-224.

26. Zakon o pedagogickych pracovnicich № 563/2004. URL: https://www.zakonyprolidi.cz/cs/2004-563 (дата звернення: 29.04.2020).

Information about the author: Prokopchuk V. I.,

Candidate of Pedagogical Sciences, Associate Professor at the Department of Playing Musical Instruments of the Institutes of Arts

Rivne State University of Humanities 12, Stephan Bandera str., Rivne, Ukraine 